\title{
Аналіз змагальної діяльності збірної команди України з греко-римської боротьби на чемпіонатах Європи 2019-2020 років
}

\author{
Георгій Коробейніков, Андрій Воронцов, Василь \\ Костюченко, Олександр Григоренко
}

Національний університет фрізичного виховання і спорту України, Київ, Україна

Анотація. Недостатня видовищність спортивної боротьби і спроби Міжнародного олімпійського комітету виключити їі з програми Олімпійських ігор спонукали Об'єднаний світ боротьби (UWW) до зміни правил змагань, що стосуються мотивування спортсмена виконувати ефективні, високоамплітудні прийоми. У зв'язку з цим виникає потреба у перегляді як системи підготовки в цілому, так і її психологічної і тактичної складової борців високої кваліфікації. Мета. Проаналізувати показники змагальної діяльності висококваліфікованих борців на головних міжнародних змаганнях для подальшого фрормування оптимальних моделей змагальної діяльності. Методи. Аналіз наукової літератури, відеоаналіз змагальної діяльності, методи математичної статистики. Результати. Встановлено переважання окремих технічних дій в стійці та в партері у представників збірних команд різних країн. Більшість балів здобутих українськими атлетами, припадає на боротьбу у стійці - $60 \%$ і $40 \%$ - на положення в партері. Визначено, що найбільшу кількість балів у стійці, незалежно від вагової категорії, було здобуто в результаті активної боротьби, а бали, отримані за пасивність суперника, становили $18 \%$,

Зміни в правилах греко-римської боротьби позитивно впливають на якість виконуваних технічних дій та кількість набраних балів у змагальних поєдинках.

Ключові слова: боротьба, технічні дії, змагальна діяльність, правила змагань.

\section{Georgiy Korobeynikov, Andrii Vorontsov, Vasil Kostiuchenko, Olexandr Hryhorenko}

\section{ANALYSIS OF THE COMPETITIVE ACTIVITY OF THE NATIONAL GRECO-ROMAN WRESTLING TEAM OF UKRAINE AT THE EUROPEAN CHAMPIONSHIPS 2019-2020}

Abstract. Insufficient spectacularity of wrestling and attempts of the International Olympic Committee to exclude it from the Olympic program have prompted the United World of Wrestling (UWW) to change the competition rules concerning motivation of athletes to perform effective, high-amplitude techniques. This necessitates to review both the training system as a whole and its psychological and tactical components of highly qualified wrestlers. Objective. To analyze the indices of competitive activity of highly qualified wrestlers at the major international competitions for further formation of competitive activity optimal models. Methods. Analysis of scientific literature, video analysis of competitive activities, methods of mathematical statistics. Results. The predominance of certain technical actions in the standing position and during ground fighting of the representatives of the national teams of different countries has been established. Most of the points earned by Ukrainian athletes fall on the fight in the standing position - $60 \%$ and $40 \%-$ on the ground fighting. It was determined that the highest number of points in the standing position, regardless of weight category, was obtained as a result of active struggle, whereas the points obtained due to opponent's passivity constituted $18 \%$. Changes in the rules of Greco-Roman wrestling have a positive effect on the quality of technical actions performed and the number of points scored in competitive matches.

Keywords: wrestling, technical actions, competitive activity, competition rules.

Korobeynikov H, Vorontsov A, Kostiuchenko V, Hryhorenko O. Analysis of the competitive activity of the national GrecoRoman wrestling team of Ukraine at the European Championships 2019-2020. Theory and Methods of Physical education and sports. 2020; 4: 27-33

DOI: 10.32652/tmfvs.2020.4.27-33
Вступ. Сьогодні спортивні єдиноборства привертають до себе все більшу увагу як спортсменів, так і уболівальників, а також засобів масової інформації, потенційних спонсорів і партнерів. Міжнародний олімпійський комітет особливу увагу приділяє саме олімпійським видам боротьби, зокрема греко-римській, як одному з перших єдиноборств в історії Олімпіад. Об'єднаний світ боротьби (United World Wrestling, аналог Міжнародної федерації) намагається досягти максимуму видовищності та привабливості змагань. Тому кількість змагань у всіх вікових категоріях значно збільшилася [3, 4]. Разом 3 цим з'явилась різноманітність видів спортивних єдиноборств, які конкурують між собою у популярності та масовості. Професійні види єдиноборств порівняно з олімпійськими, стрімко розвиваються, використовуючи сучасні комерційні стратегії, залучаючи фрінансові ресурси, які сприяють динамічному розвитку неолімпійських видів спорту [1].

Спортивна боротьба - це один 3 найдавніших видів спорту, але, на жаль, у певний час була загроза виключення її з олімпійської програми. Рішення Міжнародного олімпійського комітету від 2013 р. про виключення всіх видів спортивної боротьби з олімпійської програми обумовлює необхідність подальшого розвитку боротьби з залучанням науково-методичного забезпечення [2].

у зв'язку із необхідністю зростання популярності та видовищності боротьби Об'єднаний світ боротьби протягом останніх чотирьох Олімпіад змінює правила змагання як для греко-римської, так і для вільної та жіночої боротьби. У зв'язку з цим виникає потреба у перегляді як системи підготовки в цілому, так і психологічної і тактичної підготовки борців високої квалісікації $[5,8,17]$. 
Серед останніх досліджень провідних фрахівців із спортивної боротьби спостерігається тенденція до розробки та корекції системи підготовки борців високої кваліфікації із урахуванням змін правил змагань [10, 18], здійснюються дослідження, присвячені фрункціональній підготовці борців високої кваліфрікації в сучасних умовах $[12,14]$. Серед наукової літератури є роботи, присвячені мотиваційним аспектам психологічної підготовки борців [9, 11].

Попередні дослідження вказують на важливе значення врахування індивідуально-типологічних властивостей спортсмена для засвоєння технічних навичок та фрормування тактичних стратегій змагальної діяльності у єдиноборствах $[6,7,13]$.

Україна у світі асоціюється як «борцівська держава», що має потужні традиції та славетну історію розвитку спортивної, зокрема, греко-римської боротьби. Проте зростання міжнародної конкуренції потребує детального аналізу виступу вітчизняних борців порівняно з представниками основних лідерів-конкурентів серед континентальних та світових країн.

Таким чином, відсутність досліджень, присвячених аналізу змагальної діяльності борців високої кваліфрікації із урахуванням індивідуальних особливостей, спонукає до вивчення цієї проблеми $[15,16]$.

Робота виконується відповідно до плану НДР Національного університету фізичного виховання і спорту України на 2016-2020 рр. за темою 2.9 «Управління тренувальним процесом кваліфрікованих спортсменів у силових видах спорту та єдиноборствах на основі сучасних технологій моделювання та контролю основних характеристик підготовки» (номер держреєстрації 0116U001621).

Мета дослідження - проаналізу вати показники змагальної діяльності висококваліфрікованих борців на головних міжнародних змаганнях для подальшого формування оптимальних моделей змагальної діяльності.

Методи дослідження: аналіз наукової літератури, відеоаналіз змагальної діяльності, методи математичної статистики.
Результати дослідження та їх обговорення. В межах проведених досліджень нами було виявлено сильні та слабкі сторони виступу збірної команди України 3 греко-римської боротьби на чемпіонатах Європи 2019 і 2020 рр., а також здійснено порівняльну характеристику технічних показників змагальної діяльності вітчизняних спортсменів і атлетів країн Європи

На чемпіонаті Європи 2019 р., який пройшов у Румунії, збірна команда України 3 греко-римської боротьби посіла 3-тє командне місце в загальному заліку, завоювавши одну золоту і одну бронзову медаль. Такий результат можна вважати задовільним порівняно з попередніми виступами, наприклад, у 2016 р., було досягнуто 3-й загальнокомандний результат з такими показниками: одна золота, одна срібна, одна бронзова медалі, та одне 5-те місце.

За кількістю отриманих балів спортсмени України знаходяться серед перших восьми команд із результатом 87 балів. Попереду лише команди Болгарії, Білорусі та Угорщини, при цьому спостерігається значний відрив за показниками ефективності змагальної діяльності від команд Росії, Туреччини Азербайджану, Грузії та Вірменії. Найбільш ефективній команді Росії, у якої 287 балів, збірна України поступається в 3,3 раза. Варто відмітити, другий результат, показаний командою Туреччини, що також перевищує результат українських борців у 1,8 раза. При цьому невеликий розрив за результатами 2019 р. спостерігається і 3 командами Вірменії (10 балів) та Грузії (22 бали).

Крім виграних балів необхідно також враховувати кількість програних. Як свідчать результати чемпіонату Європи 2019 р., збірна команда України в цілому програла найбільшу кількість балів (сумарно 103). Порівняно із командою Росії, яка програла в сумі 53 бали, Україна поступається в 1,9 раза. Середній показник за кількістю програних балів серед лідерів становить 81,5 бала. Це свідчить про те, що тренерському штабу необхідно приділити особливу увагу на відпрацювання захисних технічних дій.
Виходячи з візуалізації даних співвідношення виграних і програних технічних дій, бачимо, що збірні команди Росії та Туреччини мають явну перевагу, а команда України відчуває десіцит за цим показником, як і команди Угорщини, Болгарії та Білорусі (рис. 1).

Для деталізації даних було проведено поглиблений аналіз визначення співвідношення виграних і програних балів між позиціями в умовах поєдинку: партер та стійка

Збірна команда України програла 59 балів у стійці і 44 - у партері, при цьому спортсмени не змогли заповнити десріцит програних балів в обох позиціях, набравши 49 (56 \%) балів у стійці і 38 (44\%) - у партері. Варто відмітити, що збірна команда Росії як лідер чемпіонату Європи програла сумарно 52 бали, 42 з яких у стійці і 11 у партері. Кількість поєдинків, проведених російськими спортсменами, значно перевершує ті, які провели українські борці, що збільшує коесріцієнт ефективності для перших. Виходячи 3 цього, можна зробити висновок, що лідери чемпіонату Європи приділяють особливу увагу захисним діям у партері, що обумовлено сучасними правилами боротьби.

Одним із не менш важливих індикаторів $є$ співвідношення кількості зароблених і програних балів за 1 хв, 3 допомогою якого можна побачити ефективність роботи борців, а також визначити стиль ведення боротьби.

у ході аналізу було виявлено, що спортсмени збірної команди України в середньому виграють 0,7 бала за 1 хв, тоді як програють 0,83 бала, що створює дефіцит балів. Команди Угорщини, Болгарії та Білорусі мають більш низький результат за цим критерієм. 3 іншого боку, борці збірної команди Росії за 1 хв в середньому заробляють 1,59 бала, що удвічі перевершує результат більшості збірних команд, а програють лише 0,29 бала за 1 хв. Цей результат демонструє ефективність команди і доводить, що спортсмени ведуть активну боротьбу і домінують, при цьому приділяючи увагу захисним діям і контратакам.

Для детального аналізу есрективності боротьби і визначення страте- 


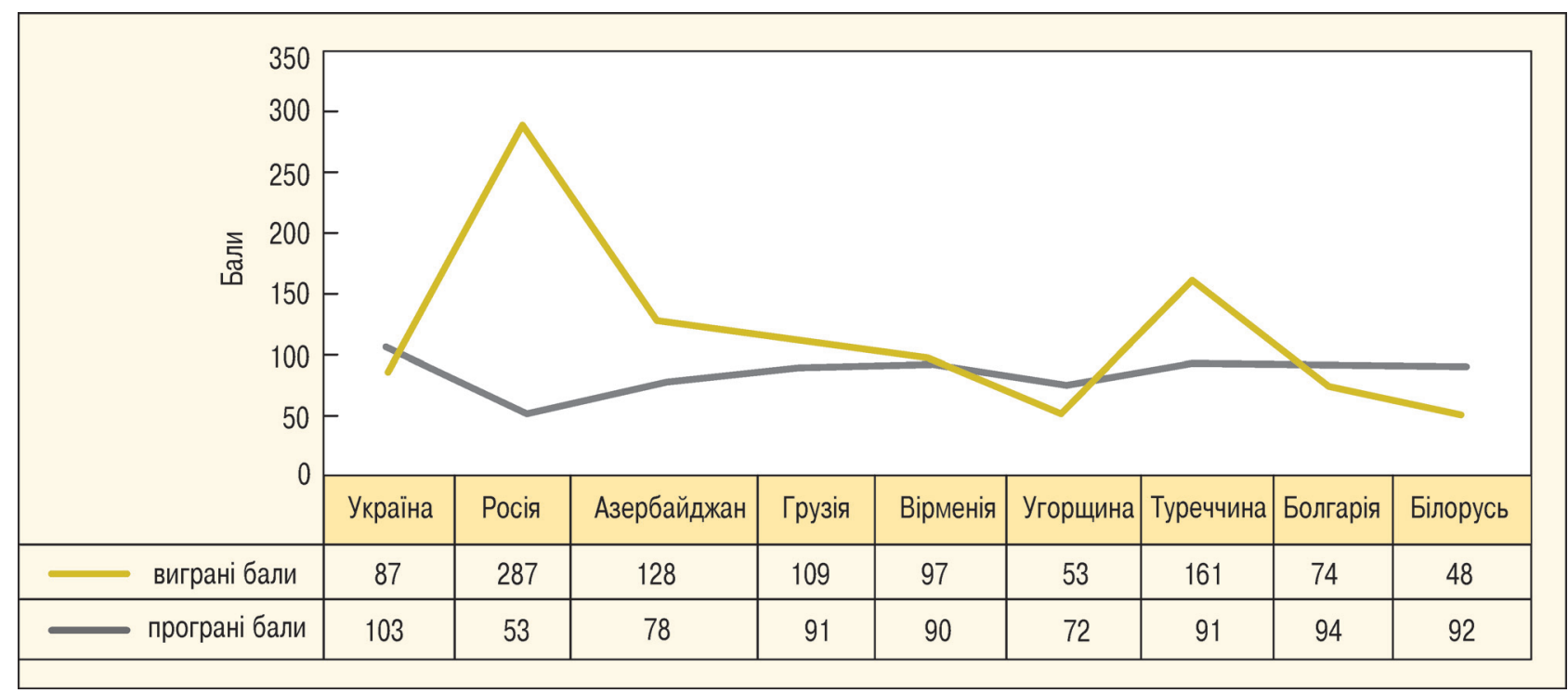

Рисунок 1 - Співвідношення виграних-програних балів збірних команд Європи з греко-римської боротьби

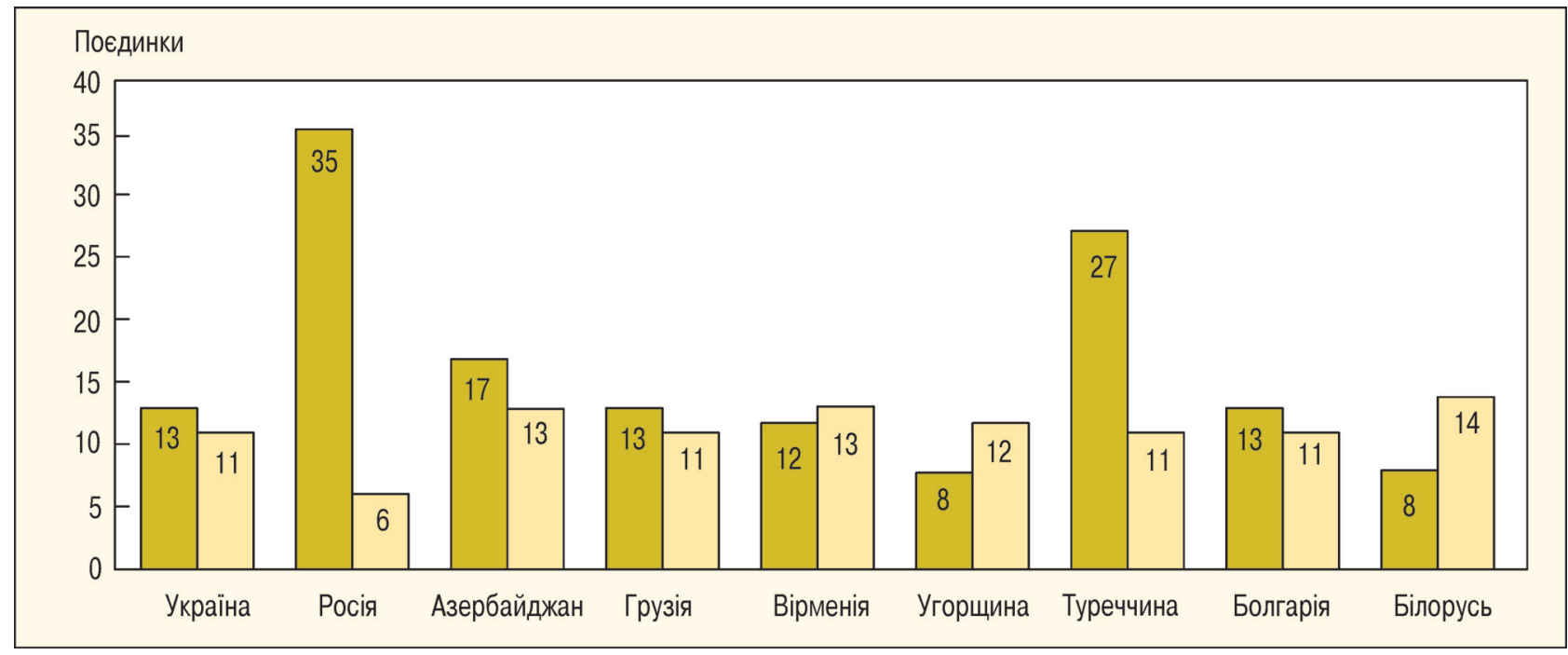

Рисунок 2 - Співвідношення виграних і програних поєдинків на чемпіонаті Європи 2019 р.: $\square$ - виграно; $\square$ - програно

гії змагальної діяльності збірних команд необхідно враховувати характеристики технічних дій. Дослідження показало, що спортсмени збірної команди України 3 греко-римської боротьби переважно використовують двобальні атаки 3 переводенням суперника у партер (16 балів з 49 зароблених у стійці). Також варто звернути увагу на те, що 12 балів було зароблено в результаті пасивності суперників. 3 огляду на сучасні правила греко-римської боротьби, цей показник є критичним і в багатьох випадках визначає долю поєдинку, оскільки пасивність суперника визначає примусовий партер.
Виходячи 3 результатів 2019 р., спортсмени України мають один з найнижчих результатів за цим показником, тоді як збірна Росії показала результат, що удвічі перевищує досягнення українських борців, набравши 27 балів за пасивність суперників. Це може свідчити про те, що українські спортсмени в цілому використовують очікувальну тактику. Цілком очевидно, що команди Росії (27 балів), Азербайджану (22 бали), Грузії (21 бал), Туреччини (34 бали) ведуть агресивну боротьбу для того, щоб змусити арбітра поставити суперника в партер у першому періоді, а також для подальшого виконання технічних дій у партері.
Результативні кидкові дії українські спортсмени проводять 3 середньою частотою $з$ положення в стійці. Найвищий результат за цим індикатором мають команди Росії та Туреччини.

у партері, українські спортсмени в 2019 р. продемонстрували різноманітні технічні дії, такі як переворот накатом (16 балів) і підйоми 3 положення партера 3 подальшим продовженням кидка (14 балів). Незважаючи на це, загальна кількість балів, зароблених у позиції партера, залишається низькою порівняно з іншими командами: збірна Росії в цілому заробила 90 балів винятково на переворотах накатом, що в 5,5 раза перевершує ре- 


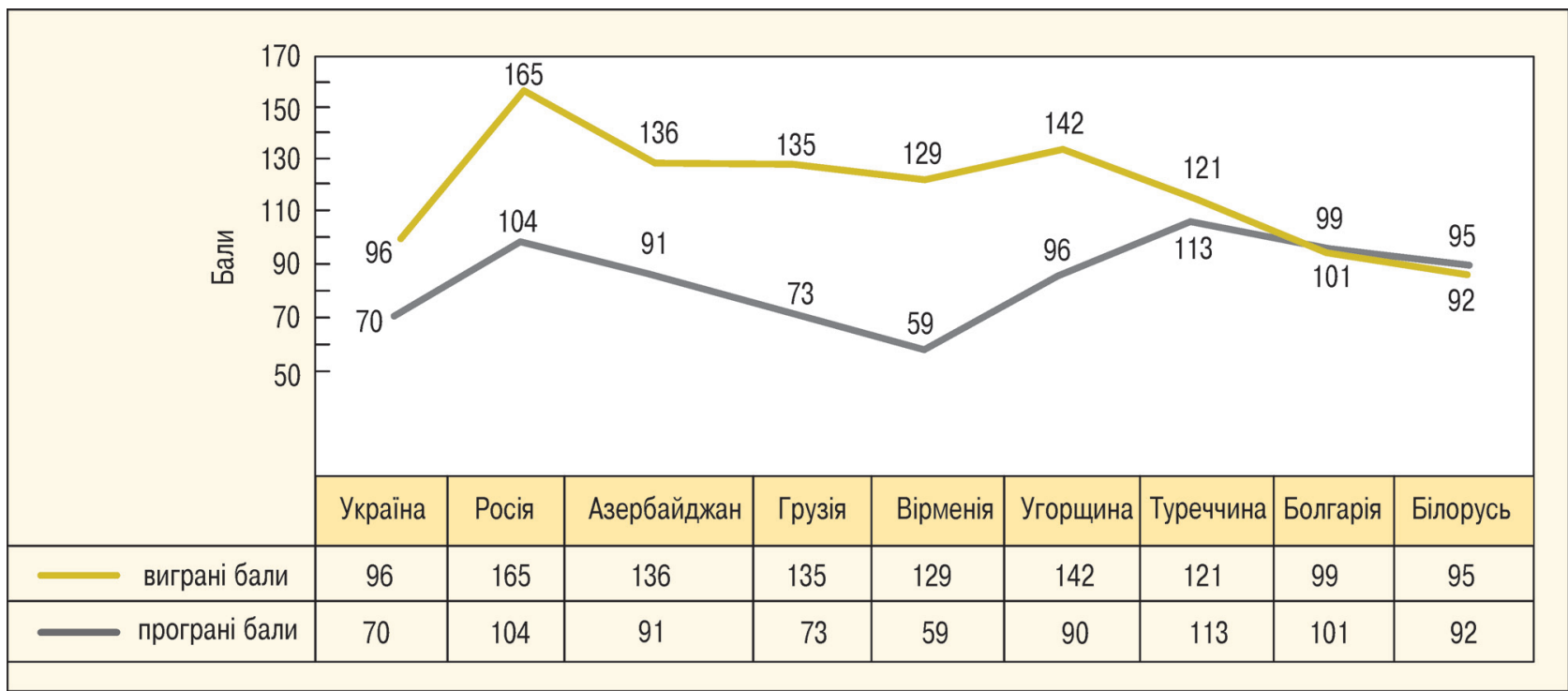

Рисунок 3- Співвідношення виграних і програних балів у борців збірних команд на чемпіонаті Європи 2020 р.

зультат збірної України. Також перевагу в переворотах накату мають команди Азербайджану (38 балів), Грузії (32 бали), Вірменії (28 балів) і Туреччини (28 балів). При цьому ефективні підйоми 3 партера із подальшим продовженням ефективного кидка демонструють спортсмени Росії (26 балів), Азербайджану (22 бали), Грузії (31 бал), Угорщини (19 балів), Болгарії (19 балів) і Білорусі (22 бали).

Варто відзначити особливості виступу інших команд Європи в 2019 р. Найбільш вразливі місця в захисті для команд Азербайджану (10 балів), Вірменії (24 бали) і Білорусі (28 балів) $€$ захист від перевороту накатом. Команда Грузії програла 20 балів у результаті переводів у партер.

На рисунку 2 представлено інформацію про кількість виграних поєдинків у порівнянні 3 програними на чемпіонаті Європи 2019 р.

Безумовними лідерами є команди Росії і Туреччини, які виграли 35 і 27 поєдинків відповідно. Показник збірної команди України має середнє значення 3 результатом 13 виграних і 11 програних зустрічей із загальним часом змагальної діяльності 124 хв. Найбільшу кількість змагального часу було проведено спортсменами команди Туреччини (201 хв), Росії (180 хв) і Азербайджану (160 хв).

На чемпіонаті Європи 2020 р., який пройшов в Італії, збірна команда України з греко-римської боротьби посі- ла 4-те командне місце в загальному заліку, завоювавши одну золоту та дві бронзові медалі. Цей результат за якістю перевершує результат 2019 р., але в командному заліку вона опустилася на одну позицію.

у 2020 р. спортсмени збірної команди України з греко-римської боротьби в сумі отримали 96 балів: $60(62,5 \%)$ було зароблено в позиції стійки і 36 (37,5 \%) у партері. Серед лідерів за цим показником збірна Україна посідає 7-ме місце, обійшовши спортсменів збірної Білорусі лише на 1 бал. Найкращий результат показала збірна команда Росії, набравши 165 балів, погіршивши минулорічний результат на 122 бали. При цьому варто відмітити, що середнє значення за сумою набраних балів серед восьми команд становить 139,75 бала. Незважаючи на певне поліпшення результатів, збірна команда України з сумарним результатом 96 балів значно поступається середньому. Цей фракт, безсумнівно, впливає на загальнокомандний показник.

На чемпіонаті Європи 2020 р. спортсмени збірної команди України в цілому програли 70 балів, продемонструвавши другий результат за цим показником, поступившись лише спортсменам збірної Вірменії, які в цілому програли 59 балів. Команда Грузії програла 73 бали, Угорщини - 90, Азербайджану - 91, Білорусі - 92, Болгарії - 101, Росії - 104, і завершує список команда Туреччини із результатом 113 балів.

Візуалізуючи дані співвідношення виграних і програних балів, бачимо, що шість команд з восьми демонструють ефрективність техніко-тактичних дій (рис. 3).

Таким чином можна побачити поліпшення ефективності змагальної діяльності команди України порівняно 32019 р. за обома показниками: збільшення на 9 виграних балів і скорочення на 33 програних. При цьому спостерігається значне зниження ефективності команди Росії, яка продемонструвала блискучий результат за всіма показниками у 2019 р. Варто відзначити, що російські спортсмени на чемпіонаті Європи 2020 р. посіли 9-те загальнокомандне місце порівняно 3 1-м у 2019 p.

Порівняння співвідношення виграних і програних балів у стійці і в партері демонструє поліпшення української збірної у захисті порівняно з результатом 2019 p.

Українські спортсмени поступилися на 53 бали в стійці, що є четвертим результатом після команд Вірменії (31 бал), Угорщини (41 бал) і Білорусі (46 балів). Що стосується позиції в партері, то вони програли 17 балів, поступившись лише команді Грузії, яка програла в цілому 8 балів у позиції партера. Загалом, українські спортсмени у стійці виграли 60 балів, а у партері - 36 . 
Для більш точного розрахунку есрективності необхідно було врахувати кількість балів, виграних і програних за 1 хв. В українських спортсменів цей показник становив виграних 0,7 бала за 1 хв і залишився незмінним порівняно з 2019 р. Але при цьому варто звернути увагу на те, що показник за кількістю програних балів за 1 хв знизився 3 позначки 0,83 бала до 0,52. Це яскраво свідчить про поліпшення захисних дій спортсменів збірної команди України (рис. 4).

Розглядаючи технічні дії, проведені спортсменами збірної України, можна відзначити, що основними технічними елементами $є$ дії в партері, а саме перевороти накатом (24 бали), а також двобальні переводи суперника в пар- тер (12 балів). Майже 18 балів було завойовано українськими борцями за пасивність суперників, а також 9 балів за рахунок виштовхування за зону килима.

Що стосується програних дій, то основними причинами є бали за пасивність (22), кидкові дії (12), переводи в партер (10), 2 бали було програно в результаті перевороту накатом, а також 8 - в результаті підйомів 3 положення партера. Українськими спортсменами 5 балів було програно за рахунок попереджень про пасивну боротьбу.

У цілому було виграно 12 поєдинків, а також 12 було програно. Як згадувалося раніше, збірна команда України в загальнокомандному заліку посіла 4-те місце, поступившись командам Азербайджану, Вірменії та Болгарії. Лідер 2020 р. команда Азербайджану в цілому провела 32 зустрічі, 22 з яких було виграно. Збірна Вірменії виграла 17 поєдинків і поступилася у 8. Збірна команда Росії виграла найбільшу кількість зустрічей (23), поступилася в 14, при цьому зайняла 9-те командне місце (рис. 5).

Таким чином, на основі аналізу двох чемпіонатів Європи (2019 та 2019 рр.) можна визначити переважання тих чи інших технічних дій у стійці та в партері у представників збірних команд різних країн.

У командному заліку збірна України в 2020 р. посіла 4-те місце, а у 2019 р. - 3-тє. Це обумовлено передовсім складом збірних команд

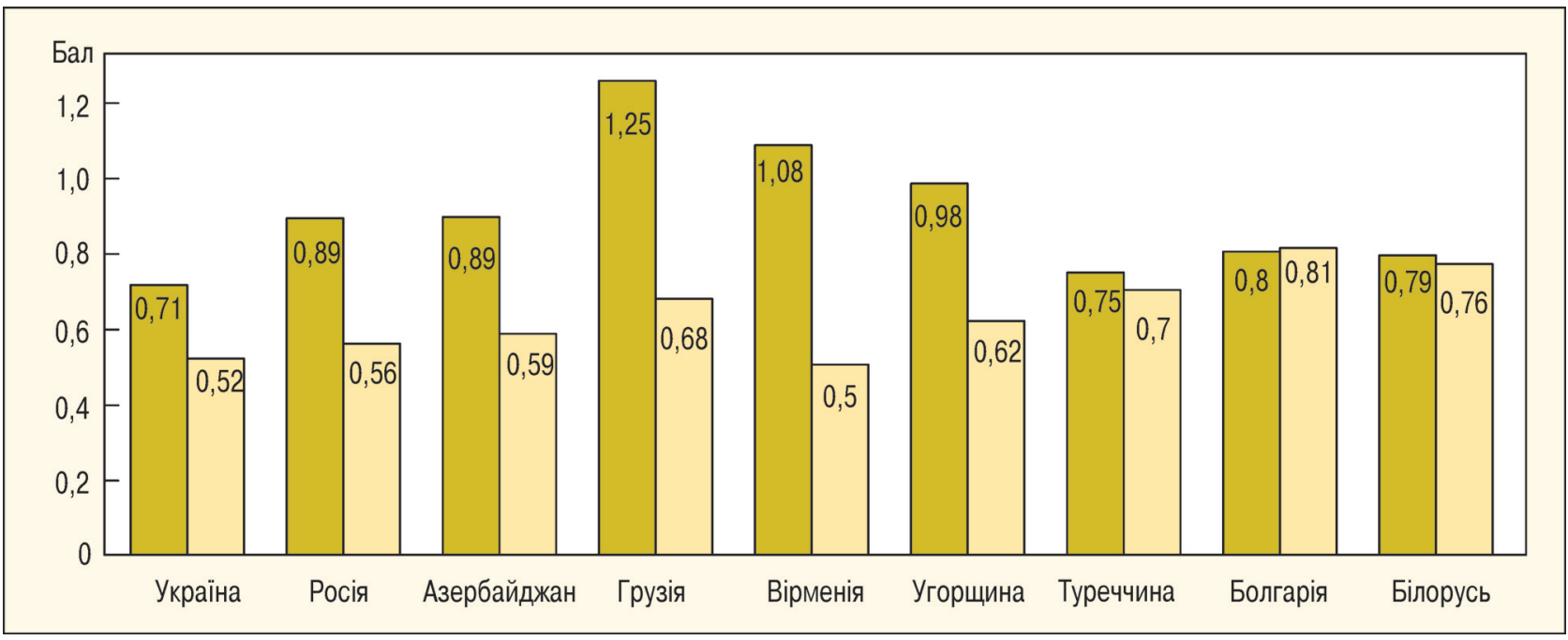

Рисунок 4 - Кількість виграних і програних балів за 1 хв серед борців збірних команд на чемпіонаті Європи 2020 р.: $\square$ - виграно; $\square$-програно

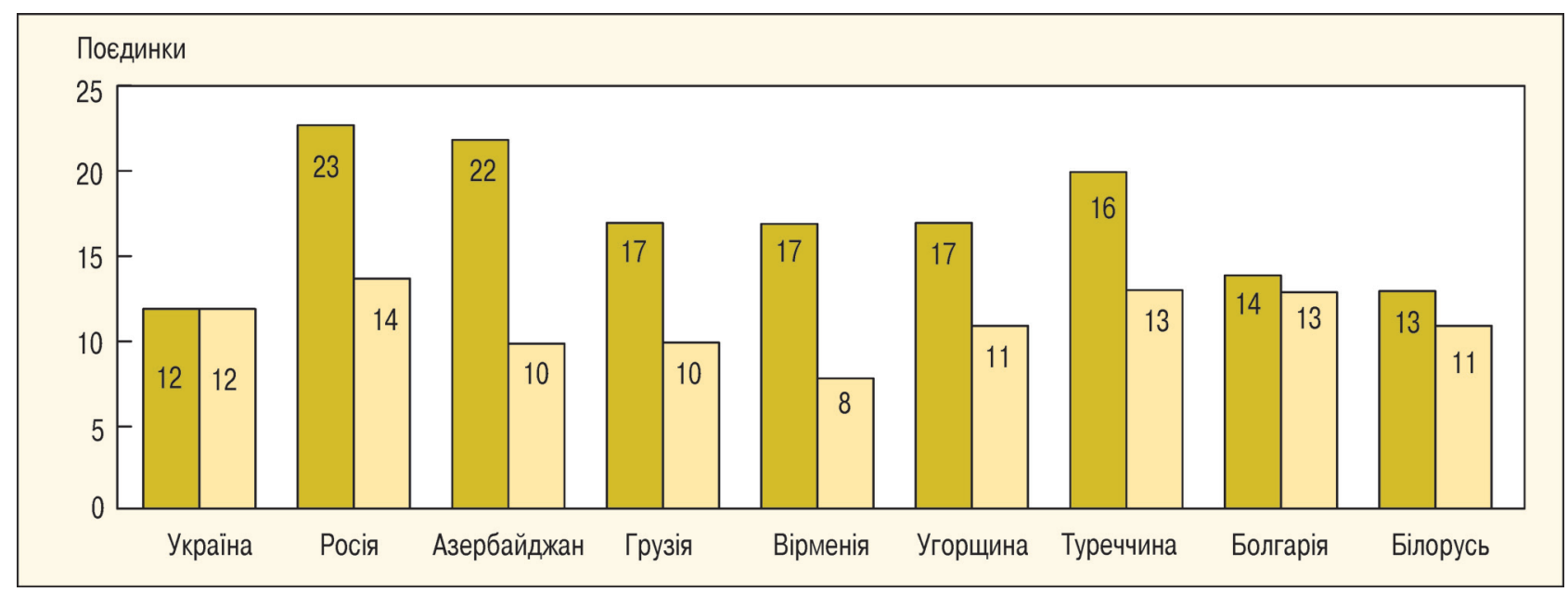

Рисунок 5- Кількість виграних та програних поєдинків борцями збірних команд на чемпіонаті Європи 2020 р.: $\square-$ виграно; $\square-$ програно 
інших країн, які на сьогодні є лідерами на Європейському континенті.

Більшість зароблених балів українськими атлетами припадає на боротьбу в стійці - 60 \% і 40 \% - на положення в партері. При цьому необхідно зазначити, що в середньому 25 \% зароблених балів припадає на накати переворотом за груди і 18 \% - за пасивність суперника. Існують певні відмінності у співвідношенні між технічними діями в стійці і в партері серед різних вагових категорій, на які слід звернути увагу тренерам у підготовчому процесі (необхідно детально вивчати кожну вагову категорію).

Виходячи 3 результатів аналізу, найбільшу кількість балів у стійці, незалежно від вагової категорії, було здобуто в результаті активної боротьби (за пасивність суперника при середньому співвідношенні 18 \% усіх зароблених балів). Це обумовлено перш за все сучасними правилами, які диктують стратегію ведення борцівського поєдинку. Другою за поширеністю технічною дією $є$ переведення суперника в партер (11 \% усіх зароблених балів). У наступну категорію потрапляють кидки зі стійки через стегно з співвідношенням 6-7 \% усіх зароблених балів. Також варто відзначити таку технічну дію, як вихід суперника за килим $-7 \%$.

Дискусія. Зміни правил змагань з боротьби та, відповідно, суддівства привели до значного зростання та активності змагальної діяльності. Аналогічний результат спостерігається також у збільшенні ефрективності технічних дій борців на провідних міжнародних змаганнях $[15,16]$.

Фактично можна зробити висновок про наявність зв'язку між зміною правил та ефективністю змагальної діяльності у спортивній боротьбі.

Зміни правил змагання стосуються мотивування спортсмена виконувати ефективні, високоамплітудні прийоми. Крім того, з боку рефері мотивується активна боротьба та карається пасивність борця

За останні роки Міжнародна федерація боротьби (United World Wrestling) удосконалила методи комунікації технічної інформації з національними федераціями та іншими заці- кавленими сторонами. Це дає можливість експертам аналізувати та обробляти дані для надання рекомендацій до вдосконалення правил спортивно боротьби, поліпшення есективності системи проведення турнірів, а також сприяє зацікавленості з боку національних фредерацій в скаутингу для аналізу суперників $[15,17]$.

Така стратегія за допомогою детального технічного аналізу дає можливість визначати сильні та слабкі сторони суперників і ефрективність виступів команд. За правильної інтерпретації тренерський штаб отримує цінну інформацію про тактичні методи тієї чи іншої команди, а в деяких випадках інформація може бути надана по кожному спортсмену. Завдяки цій інформації тренери зможуть індивідуалізувати тренувальний процес. Більшість передових країн використовує відеоаналіз і методи математичних розрахунків для визначення стратегії ведення поєдинку аж до десяти секундних відрізків. Слід зазначити, що країни які використовують ці технології, значно поліпшили ефективність виступів як на континентальному, так і на світовому рівнях.

у результаті дослідження було визначено командних лідерів Європи у греко-римській боротьбі та командні місця, які посіла збірна України у 2019-2020 рр. Було підтверджено наші попередні дослідження, де показано, що у борців збірної команди України переважає атакуюча стратегія змагальної діяльності протягом ведення поєдинку $[5,15]$. Також було визначено відмінності у показниках змагальної діяльності лідерів, як збігаються 3 даними дослідників [8 $10,17]$

Отримані результати дають можливість виявити слабкі сторони підготовки збірної команди України 3 греко-римської боротьби, що виявилися під час чемпіонатів Європи 2019-2020 рр., та спрямувати зусилля тренерського штабу на усунення недоліків у техніко-тактичній підготовці спортсменів.

\section{Висновки:}

1. Показники надійності захисту спортсменів збірної команди України поступаються лідерам чемпіонату Європи у стійці і в партері.

2. Переважну більшість дій, що виконали українські борці, становили двобальні прийоми, а також бали були отримані в результаті пасивності суперників.

3. Українські спортсмени в цілому використовують очікувальну тактику.

Перспективи подальших досліджень полягають у можливості використання визначених показників змагальної діяльності провідних збірних команд Європи для побудови цільових моделей, що можуть бути використані в техніко-тактичній підготовці українських борців.

Конфлікт інтересів. Автори заявляють, що відсутній будь-який конфрлікт інтересів.

\section{ЛITEPATУPA}

1. Борисова 0, Козлова Е. Профессионализация и коммерциализация в олимпийском спорте (на материале тенниса и легкой атлетики). Наука в олимпийском спорте; 2017.4:61-71.

2. Павленко ЮО. Состав и структура системы научно-методического обеспечения подготовки спортсменов к Олимпийским играм. В: Єрмаков СС, редактор. Педагогіка, психологія і медико-біологічні проблеми фіз. виховання і спорту: зб. наук. праць; 2011.12:68-72.

3. Платонов ВН. Периодизация спортивной тренировки. Общая теория и ее практическое применение. Киев: Олимпийская лит. 2013;624

4. Платонов ВН, Павленко ЮА, Томашевский ВВ. Подготовка национальных команд к Олимпийским играм. Киев: Олимпийская лит. 2012;310.

5. Тропин ЮН, Бойченко НВ. Анализ технико-тактической подготовленности высококвалифицированных борцов греко-римского стиля после изменений правил соревнований. Слобожанський науково-спортивний вісник. 2014.2:117-20.

6. Шиян ВВ. Сравнительный анализ эффективности совершенствования специальной работоспособности дзюдоистов различных весовых категорий в макроцикле предсоревновательной подготовки. Ученые записки университета им. ПФ Лесгафта; 2017.11:295300.

7. Barbas I, Fatouros IG, Douroudos II, Chatzinikolaou A, Michailidis Y, Draganidis D, Jamurtas AZ, Nikolaidis MG, Parotsidis C, Theodorou AA, Katrabasas I. Physiological and performance adaptations of elite Greco-Roman wrestlers during a one-day tournament. European journal of applied physiology. 2011 Jul 1;111(7):1421-36. doi:10.1007/s00421-010-1761-7.

8. Curby DG. Effect of uniform color on outcome of match at Senior World Wrestling Championships 2015. International Journal of Wrestling Science. 2016 Jan 2;6(1):62-4. doi:10.1080/21615 667.2016.1210266

9. Korobeynikov GV, Korobeynikova LG, Romanyuk LV, Dakal NA, Danko GV. Relationship of psychophysiological characteristics with different levels of motivation in judo athletes 
of high qualification. Pedagogics, psychology, medical-biological problems of physical training and sports. 2017(6):272-8. doi: 10.15561/ 18189172.2017.0603.

10. López-González DE, Miarka B. Reliability of a new time-motion analysis model based on technical-tactical interactions for wrestling competition. International Journal of Wrestling Science. 2013 Jun 1;3(1):21-34.

11. Martins P, Pedro S. Motivational Regula tions and Recovery in Olympic Wrestlers. International Journal of Wrestling Science. 2017 Jul 3;7(12):27-34. doi:10.1080/21615667.2017.1346345.

12. Mirzaei B, Rahmani-Nia F, Moghadam MG Ziyaolhagh SJ, Rezaei A. The effect of ramadan fasting on biochemical and performance parameters in collegiate wrestlers. Iranian journal of basic medical sciences. 2012 Nov;15(6):1215.

13. Radchenko YA. Analysis of the competitive activities of ukrainian champions with the strongest fighters of world (based on world championship in greco-roman wrestling in 2011). Pedagogika, psihologia ta mediko-biologicni problem fizicnogo vihovanna i sportu. 2012 Jun 1:5:108-11.

14. Sybil M, Pervachuk R, Zahura F, Stelmakh $\mathrm{Y}$, Bodnar I. Considering the current balance between lactate and alactate mechanisms of energy supply in preparation of free style wrestlers. Journal of Physical Education and Sport. 2018 Oct 1;18:1826-30. doi:10.7752/jpes.2018.s4267.

15. Tropin $Y$, Korobeynikov G, Curby D, Vorontsov A, \& Shatskih V. (2017). Model characteristics of sensorimotor reactions and specific perceptions of wrestlers among different weight categories. International Journal of Wrestling Science. 9:2, 14-18.

16. Tünnemann $\mathrm{H}$. Evolution and adjustments for the new rules in wrestling. International Journa of Wrestling Science. 2013 Sep 1;3(2):94-104.

17. Tünnemann H, Curby DG. Scoring analysis of the wrestling from the 2016 Rio Olympic Games. International Journal of Wrestling Science. 2016 Jul 2;6(2):90-116. doi:10.1080/21615667.20 17.1315197

18. Yamashita D, Arakawa $H$, Arimitsu $T$, Wada T, Yumoto K, Fujiyama K, Nagami T, Shimizu S. Physiological Profiles of International-and Collegiate-Level Japanese Male Freestyle Wrestlers in the Lightweight Classes. International Journa of Wrestling Science. 2017 Jul 3;7(1-2):21-5. doi: 10.1080/21615667.2017.1341572.

\section{LITERATURE}

1. Borisova 0, Kozlova E. Professionalization and commercialization in the Olympic sport (tennis and track and field. Nauka v Olimpiyskom sporte 2017.4:61-71.

2. Pavlenko YO. Content and structure of the system of scientific and methodical support of athletes' preparation for the Olympic Games. In: lermakov SS, editor. Pedahohika, psykholohiia ta medyko-biolohichni problem fizychnoho vykhovannia i sportu: zb. nauk. prats; 2011.12:68-72.

3. Platonov VN. Sports training periodization. General theory and its practical applications. Kiev: Olimpiyskaya literatura. 2013;624.
4. Platonov VN, Pavlenko YA, Tomashevsky VV. National teams' preparation for the Olympic Games. Kiev: Olimpiyskaya literatura. 2012;310.

5. Tropin YN, Boychenko NV. Analysis of technico-tactical fitness of highly skilled GrecoRoman wrestlers after the change of competition rules. Slobozhanskyi naukovo-sport. visnyk. 2014.2:117-20.

6. Shiyan VV. Comparative analysis of the efficiency of improving special work capacity of judokas of different weight categories in precom petitive preparation macrocycle. Uchenyye zapisk universiteta imeni P. Lesgafta; 2017.11:295-300

7. Barbas I, Fatouros IG, Douroudos II, Chatzinikolaou A, Michailidis $Y$, Draganidis D, Jamurtas AZ, Nikolaidis MG, Parotsidis C, Theodorou AA, Katrabasas I. Physiological and performance adaptations of elite Greco-Roman wrestlers during a one-day tournament. European journal of applied physiology. 2011 Jul 1;111(7):1421-36 doi:10.1007/s00421-010-1761-7.

8. Curby DG. Effect of uniform color on outcome of match at Senior World Wrestling Championships 2015. International Journal of Wrestling Science. 2016 Jan 2;6(1):62-4. doi:10.1080/21615 667.2016 .1210266

9. Korobeynikov GV, Korobeynikova LG Romanyuk LV, Dakal NA, Danko GV. Relationship of psychophysiological characteristics with different levels of motivation in judo athletes of high qualification. Pedagogics, psychology, medical-biological problems of physical training and sports. 2017(6):272-8. doi: 10.15561/18189172.2017.0603.

10. López-González DE, Miarka B. Reliability of a new time-motion analysis model based on technical-tactical interactions for wrestling competition. International Journal of Wrestling Science. 2013 Jun 1;3(1):21-34.

11. Martins P, Pedro S. Motivational Regula tions and Recovery in Olympic Wrestlers. Interna- tional Journal of Wrestling Science. 2017 Jul 3:7(1 2):27-34. doi:10.1080/21615667.2017.1346345.

12. Mirzaei B, Rahmani-Nia F, Moghadam MG Ziyaolhagh SJ, Rezaei A. The effect of ramadan fasting on biochemical and performance parameters in collegiate wrestlers. Iranian journal of basic medical sciences. 2012 Nov;15(6):1215.

13. Radchenko YA. Analysis of the competitive activities of ukrainian champions with the strongest fighters of world (based on world championship in greco-roman wrestling in 2011). Pedagogika, psihologia ta mediko-biologicni problem fizicnogo vihovanna i sportu. 2012 Jun 1:5:108-11.

14. Sybil M, Pervachuk R, Zahura F, Stelmakh Y, Bodnar I. Considering the current balance between lactate and alactate mechanisms of energy supply in preparation of free style wrestlers. Journal of Physical Education and Sport. 2018 Oct 1:18:1826-30. doi:10.7752/jpes.2018.s4267.

15. Tropin Y, Korobeynikov G, Curby D, Vorontsov A, \& Shatskih V. (2017). Mode characteristics of sensorimotor reactions and specific perceptions of wrestlers among different weight categories. International Journal of Wrestling Science. 9:2, 14-18.

16. Tünnemann H. Evolution and adjustments for the new rules in wrestling. International Journa of Wrestling Science. 2013 Sep 1;3(2):94-104.

17. Tünnemann $\mathrm{H}$, Curby DG. Scoring analysis of the wrestling from the 2016 Rio Olympic Games. International Journal of Wrestling Science. 2016 Jul 2:6(2):90-116. doi:10.1080/21615667.20 17.1315197

18. Yamashita D, Arakawa $\mathrm{H}$, Arimitsu $T$, Wada T, Yumoto K, Fujiyama K, Nagami T, Shimizu S. Physiological Profiles of International-and Collegiate-Level Japanese Male Freestyle Wrestlers in the Lightweight Classes. International Journal of Wrestling Science. 2017 Jul 3;7(1-2):21-5. doi 10.1080/21615667.2017.1341572.

Надійшла 26.11.2020

\section{ІНФОРМАЦІЯ ПРО АВТОРІВ}

Коробейніков Георгій Валерійович https://orcid.org/0000-0002-1097-4787, k.george.65.w@ gmail.com

Воронцов Андрій Валерійович https://orcid.org/0000-0003-2733-4177, vorontsov.andrey1988@ gmail.com

Костюченко Василь Іванович https://orcid.org/0000-0001-5562-760X, kosstiuchenko71@gmail. com

Григоренко Олександр Валерійович https://orcid.org/0000-0002-0052-669X, s.g.v@bk.ru

Національний університет фрізичного виховання і спорту України,

03150, Київ, вул. Фізкультури, 1

\section{INFORMATION ABOUT THE AUTHORS}

Korobeynikov Georgiy https://orcid.org/0000-0002-1097-4787, k.george.65.w@gmail.com Vorontsov Andrii https://orcid.org/0000-0003-2733-4177, vorontsov.andrey1988@gmail.com Kostiuchenko Vasil https://orcid.org/0000-0001-5562-760X, kosstiuchenk071@gmail.com Grigorenko Olexandr https://orcid.org/0000-0002-0052-669X, s.g.v@bk.ru

National University of Ukraine on Physical Education and Sport,

03150, Kyiv, Fizkul'tury str., 1 